\title{
Penilaian indeks kualiti air Alur Ilmu UKM, sub-lembangan Sungai Langat
}

\author{
Anne Sakina Iman Syaiffudin ${ }^{1}$, Mohd Ekhwan Toriman ${ }^{1}$ \\ ${ }^{1}$ Pusat Kajian Pembangunan, Sosial dan Persekitaran (SEEDS), \\ Fakulti Sains Sosial dan Kemanusiaan, Universiti Kebangsaan Malaysia \\ Correspondence: Anne Sakina (email: annesakinah@yahoo.com)
}

Received: 27 December 2019; Accepted: 22 February 2020; Published: 27 February 2020

\begin{abstract}
Abstrak
Artikel ini membincangkan tentang kajian penilaian kualiti air Alur Ilmu, Universiti Kebangsaan Malaysia (UKM) dengan melibatkan 10 stesen persampelan. Keseluruhan panjang sungai ini adalah sekitar $1.79 \mathrm{~km}$ bermula dengan stesen persampelan pertama iaitu di Tasik Ghazali dan berakhir di Masjid UKM. Masalah kualiti air yang kian meruncing dari semasa ke semasa telah menyebabkan keadaan fizikal Alur Ilmu dilihat semakin tercemar dan tidak menyenangkan. Justeru, satu kajian kualiti air yang terkini telah dilakukan bermula pada Jun 2019 sehingga Ogos 2019 dengan menggunakan kaedah ex-situ dan in-situ di kawasan kajian. Parameter kajian yang terlibat adalah seperti Oksigen Terlarut (DO), Permintaan Oksigen Kimia (COD), Jumlah Pepejal Terampai (TSS), Pemintaan Oksigen Biokimia (BOD), $\mathrm{pH}$ dan Ammonia Nitrogen $\left(\mathrm{NH}_{3}-\mathrm{N}\right)$. Sebanyak empat kali data diambil untuk mewakili kajian semasa cuaca kering dan sebanyak lima kali semasa cuaca basah atau selepas hujan. Indeks Kualiti Air (IKA) oleh Jabatan Alam Sekitar (JAS) Malaysia telah digunakan untuk mengukur tahap pencemaran dan kesesuaian jenis guna air seperti yang disarankan oleh Piawaian Kualiti Air Kebangsaan (NWQS). Seterusnya, keseluruhan hasil kajian dibandingkan untuk membezakan keadaan kualiti air semasa cuaca kering dan cuaca basah. Penggunaan aplikasi ArcGIS turut digunakan dalam konteks spatial khususnya untuk mewakili hasil data IKA di setiap stesen persampelan yang telah ditetapkan. Dapatan kajian mendapati, keadaan stesen persampelan di bahagian hulu dan tengah Alur Ilmu mencatatkan kelas IKA yang tercemar berbanding di kawasaan hilir. Kemerosotan kualiti air di stesen persampelan hulu dan tengah Alur Ilmu adalah disebabkan oleh keterdedahan kawasan stesen persampelan dengan kafeteria dan fakulti. Kerjasama daripada pelbagai pihak khususnya segenap lapisan warga UKM amat diperlukan bagi menjamin kelestarian kualiti air di Alur Ilmu ini dapat dijaga dan dipelihara.
\end{abstract}

Kata kunci: cuaca kering, cuaca basah, ex-situ, ArcGIS, in-situ, kualiti air. 


\title{
Assessment of water quality index of Alur Ilmu UKM, a sub-cathment of Langat River
}

\begin{abstract}
This article discusses the study of water quality assessment of the Alur Ilmu, Universiti Kebangsaan Malaysia by involving 10 sampling stations. The entire length of the river is about $1.79 \mathrm{~km}$ starting with the first garbage station at Lake Ghazali and ending at Masjid UKM. Increasing water quality issues from time to time have caused the physical state of the science flow to become increasingly polluted and unpleasant. Therefore, a recent water quality study was conducted from June 2019 to August 2019 using ex-situ and in-situ methods in the study area. The study parameters involved are Dissolved Oxygen (DO), Chemical Oxygen Demand (COD), Total Suspended Solids (TSS), Biochemical Oxygen Demand (BOD), $\mathrm{pH}$ and Nitrogen Ammonia $\left(\mathrm{NH}_{3}-\mathrm{N}\right)$. The data has been collected four times to represent the study during dry weather and five times during wet or after rain. The Water Quality Index (WQI) by the Department of the Environment (DOE) of Malaysia has been used to measure the level of pollution and suitability of water used as suggested by the National Water Quality Standards (NWQS). Furthermore, the overall results of the study were compared to distinguish between water quality during dry and wet weather. The used ArcGIS applications have been used in spatial contexts in particular, for each WQI results data at each location. The study found that the sampling center at the upstream and middle of the science stream recorded an impaired WQI class compared to downstream controls. The deterioration of water quality at the upstream and central sampling stations was due to the exposure of the station sampling area to the cafeteria and faculty. Collaboration from various parties in UKM is essential to well-balanced and ensure the quality of water in this Alur Ilmu $\mathrm{UKM}$ is maintained.
\end{abstract}

Keywords: dry weather, wet weather, ex-situ, ArcGIS, in-situ, water quality.

\section{Pengenalan}

Air merupakan salah satu komponen asas kepada hidupan bumi selain sumber semula jadi selepas daripada udara dan logam-logam berat yang diperlukan untuk semua hidupan dan bukan hidupan. Bagi tujuan aktiviti keberterusan hidup haiwan dan tumbuhan, air merupakan salah satu sumber utama yang diperlukan melalui proses pemanasan bagi menjana sumber makanan (WHO, 2006). Lebih daripada 1.2 bilion orang terpaksa berhadapan dengan masalah kekurangan air bersih sekaligus akan menambahkan kebimbangan yang lebih serius (Shaharuddin \& Noorazuan, 2006; Global Water Partnership, 2009; Tuan Pah Rokiah et al., 2015; Tuan Pah Rokiah \& Hamidi, 2016). Justeru, kepentingan air bersih daripada kualiti air yang baik kepada hidupan khususnya manusia, perlu lebih diberi perhatian dan kerjasama yang jitu daripada setiap individu dan masyarakat.

Dalam pada itu, tahap kualiti air mempunyai hubungan secara langsung dengan kekerapan dan intensiti hujan dalam satu-satu masa. Secara fizikalnya, jumlah hujan yang tinggi mampu meningkatkan proses hakisan dan pemendapan, di samping meningkatkan kadar luahan sesebuah sistem saliran dan seterusnya akan memberi impak kepada perubahan tahap kualiti air sungai tersebut. Walau bagaimanapun, kewujudan hidupan organik dan bukan organik dalam sistem saliran juga sebenarnya mampu mempengaruhi kualiti air. Pepejal terampai yang terhasil daripada aktiviti pembangunan tanah, perlombongan dan 
pembandaran menyebabkan berlakunya hakisan tanih yang merupakan salah satu petunjuk pencemaran air dan kebiasaannya ia terdiri daripada lumpur, zarah pasir halus kelodak dan sisa halus mineral (Azahan et al., 2001). Justeru itu, sebuah kajian kualiti air dengan menggunakan kaedah Indeks Kualiti Air (IKA) bagi mengkaji tahap kualiti air selepas dan sebelum hujan dan seterusnya dipersembahkan dalam bentuk pemetaan dengan menggunakan aplikasi ArcGIS.

\section{Sorotan literatur}

Kualiti air dalam sesebuah badan air dapat dikaitkan dengan kawasan tadahan air di persekitarannya. Kebiasaannya bagi sesebuah sungai yang bersifat konkrit atau 'sungai bandar', di kawasan hulu saliran airnya masih belum dipengaruhi oleh unsur-unsur pencemaran, akan tetapi di bahagian tengah dan hilirnya biasanya telah tercemar dengan agak teruk disebabkan saliran telah melalui kawasan-kawasan yang terdapat pelbagai aktiviti manusia yang telah menyumbang ke arah pencemaran. Tambahan pula, pertambahan bilangan penduduk dan sistem pembuangan sisa kumbahan serta bahan kimia daripada sumber-sumber tertentu juga telah menyebabkan kemerosotan kualiti air. Jika semua perkara ini terus berlaku tanpa sebarang langkah mitigasi dilakukan, maka akan berlakunya ancaman kepada kesihatan manusia dan persekitaran khususnya hidupan akuatik. Proses pembangunan atau perubahan guna tanah seringkali memberi kesan kepada ketidakseimbangan kitaran semula jadi khususnya imbangan air dan tanah. Impak yang agak ketara juga dapat dilihat pada kualiti dan kuantiti air dalam sesebuah sistem lembangan dan seterusnya menggalakkan lagi kepada bencana alam sekitar. Antaranya adalah seperti bencana banjir kilat iaitu ia berpunca daripada ketidakseimbangan kitaran air, masalah sistem pengairan serta pertambahan kawasan berkonkrit dan tepubina (Bedient \& Huber, 1988; Lazaro, 1990; Schueler, 1994).

Dalam konteks pencemaran air, menurut Miller (2005) sesebuah jasad air itu tercemar apabila berlaku perubahan terhadap kualiti air yang disebabkan oleh sebarang bentuk pencemaran fizikal, kimia dan biologi. Ia akan memberi kesan kepada organisma dan menjadikan air tersebut tidak sesuai untuk digunakan. Di samping itu, isu pencemaran air bukanlah sebuah perkara baru yang dihadapi oleh negara Malaysia, menurut Katiman dan Asmah (2006) terdapat tiga aspek pencemaran air berlaku iaitu melalui pencampuran, pencairan dan larutan kesan daripada proses pereputan biokimia atau proses pemendakan. Dalam keadaan semula jadi, proses ini mudah berlaku terutamanya ketika terlalu banyak pengumpulan bahan-bahan mendakan di dalam badan air. Justeru, ini menunjukkan takungan air sungai mengalami proses semula jadi eutrofikasi atau proses pengkayaan nutrien yang dipengaruhi oleh aktiviti manusia dan semula jadi.

Kemajuan teknologi maklumat pada masa kini seperti Sistem Maklumat Geografi (GIS) telah membolehkan aktiviti peramalan pencemaran air dilakukan dengan menyimpan, mengolah, mengurus, menganalisis dan memaparkan data ruangan untuk kemudahan semasa membuat keputusan, semasa perancangan dan pengurusan. Selain daripada itu, GIS penting dalam konteks memahami dan mempengaruhi secara aktif proses-proses teknologi, sosioekonomi, ruang dan alam sekitar dengan cara lebih rasional dan bersistematik (Ruslan \& Noresah, 1998; Nasir, 2006).

Teknik pemetaan secara interpolasi boleh digunakan sebagai model peramalan impak. Sebagai contoh, pangkalan data dari pelbagai sumber serta data sosioekonomi boleh digunakan untuk memodelkan perubahan guna tanah, kualiti air sungai dan air bawah tanah, kesan fizikal dan kemanusiaan dengan cepat dan hasilnya boleh dipersembahkan dalam bentuk grafik atau jadual yang berkualiti tinggi (Hassan et al., 2018; Norhazliana Eazreen, 
2006; Rasyidah, 2014; Veerabhadram, 2009). Justeru itu, artikel ini cuba menggunakan aplikasi GIS dalam mempersembahkan data-data kualiti air bagi setiap stesen persampelan di sepanjang Alur Ilmu, UKM.

\section{Metodologi dan kawasan kajian}

Alur Ilmu UKM merupakan sebuah badan air utama yang melalui kampus induk UKM dan menerima luahan daripada Hutan Pendidikan Alam (Hutan Simpan Kekal Bangi dan Hutan Pendidikan Alam). Luas lembangan Alur Ilmu ialah kira-kira 68.95 hektar. Alur Ilmu turut menerima lebihan air larian daripada air hujan, air bawah tanah dan apa-apa jenis cecair dilepaskan sebelum ia mengalir ke dalam Sungai Langat, Selangor (Mazlin et al., 2005).

Alur Ilmu ini pada asalnya merupakan sungai semula jadi tetapi pada sekitar tahun 1970-an, saliran Alur Ilmu ini diubah kepada bentuk konkrit (Din et al., 2012). UKM yang juga terletak di dalam daerah Hulu Langat, Selangor ini merupakan salah satu institut pengajian tinggi terbesar di kawasan Bangi selain daripada Kolej Universiti Islam Malaysia (KUIS) dan German Malaysia Institute (GMI). Rajah 1 menunjukkan kedudukan kawasan UKM di dalam kawasan Hulu Langat, Selangor.

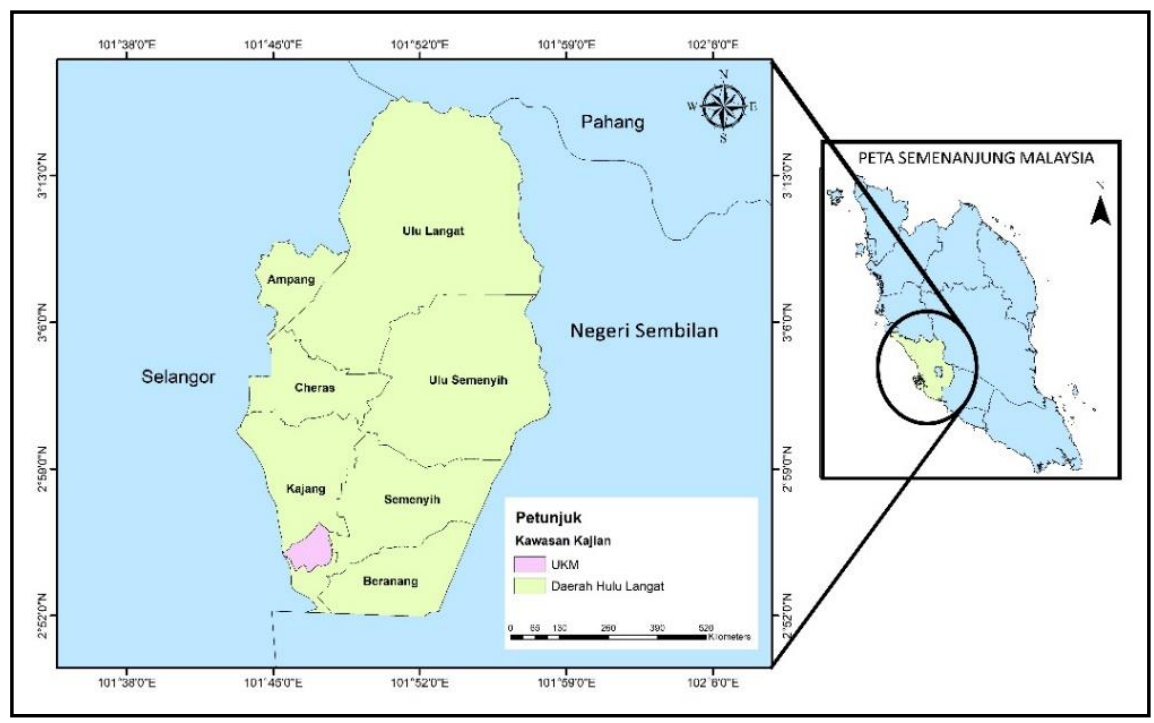

Rajah 1. Kedudukan UKM di Hulu Langat, Selangor

Menurut Mohd Hafiyyan et al. (2017), status kualiti air di Alur Ilmu pernah mencatatkan bacaan yang rendah iaitu dari Kelas II pada tahun 1999 kepada Kelas IV pada tahun 2012 (Chong, 1999; Din et al., 2012). Aktiviti antropogenik seperti aktiviti pembangunan serta pembinaan infrastruktur dan aktiviti harian manusia secara tidak langsung telah mengganggu ekosistem dan kualiti air di Alur Ilmu. Selain itu, pengaliran sisa bahan kimia daripada makmal dan sisa bahan buangan daripada kafeteria turut menyumbang kepada kemerosotan kualiti air (Din et al., 2012).

Kajian ini telah memilih 10 stesen persampelan yang terdapat dalam lembangan Alur Ilmu dengan mengambilkira faktor kedudukan punca pembuangan air dari kawasan tertentu seperti kolej kediaman, dewan kuliah, tempat meletak kenderaan, bangunan pentadbiran dan kafeteria (Jadual 1). Pemilihan 10 stesen persampelan ini adalah berdasarkan keberadaan inlet, kemasukan air larian permukaan, aktiviti pembangunan, dan kawasan yang berisiko mengalirkan air yang tercemar (Rajah 2). Selain itu, faktor geografi dan kedudukan setiap stesen persampelan juga diambil kira bagi melihat setiap perubahan daripada setiap impak 
yang terjadi di sepanjang Alur Ilmu tersebut. Terdapat dua stesen persampelan inlet daripada 10 stesen persampelan ini iaitu di SL3 dan SL10.

Jadual 1. Kedudukan stesen cerapan dan justifikasi setiap stesen persampelan

\begin{tabular}{|c|c|c|}
\hline No. Stesen Persampelan & Koordinat & Justifikasi pemilihan sampel \\
\hline SL 1 & $\begin{array}{l}2^{\circ} 92^{\prime} 39.41 \mathrm{U} \\
101^{\circ} 77^{\prime} 92.18 \mathrm{~T}\end{array}$ & $\begin{array}{l}\text { Efluen kawasan daripada Bangunan Sains Nukleur } \\
\text { (Hulu Alur Ilmu) }\end{array}$ \\
\hline SL 2 & $\begin{array}{l}2^{\circ} 55^{\prime} 21.00 \mathrm{U} \\
101^{\circ} 466^{\prime} 54.10 \mathrm{~T}\end{array}$ & $\begin{array}{l}\text { Inlet yang menerima aliran air dari longkang } \\
\text { Bangunan Sains Kimia dan tempat meletak } \\
\text { kenderaan FST }\end{array}$ \\
\hline SL 3 & $\begin{array}{l}2^{\circ} 92^{\prime} 43.43 \mathrm{U} \\
101^{\circ} 78^{\prime} 20.04 \mathrm{~T}\end{array}$ & $\begin{array}{l}\text { Efluen daripada bangunan DAM, bangunan Geologi, } \\
\text { Kafeteria FST dan FEP }\end{array}$ \\
\hline SL 4 & $\begin{array}{l}2^{\circ} 92^{\prime} 60.98 \mathrm{U} \\
101^{\circ} 78^{\prime} 14.54 \mathrm{~T}\end{array}$ & Efluen daripada PTSL dan FEP \\
\hline SL 5 & $\begin{array}{l}2^{\circ} 92^{\prime} 67.66 \mathrm{U} \\
101^{\circ} 78^{\prime} 08.16 \mathrm{~T}\end{array}$ & $\begin{array}{l}\text { Kawasan yang menerima aliran air dari longkang } \\
\text { Bangunan Bilik Kuliah FSSK dan Pusanika }\end{array}$ \\
\hline SL 6 & $\begin{array}{l}2^{\circ} 92^{\prime} 73.13 \mathrm{U} \\
101^{\circ} 78^{\prime} 04.90 \mathrm{~T}\end{array}$ & $\begin{array}{l}\text { Kawasan yang menerima aliran air dari Kafeteria } \\
\text { Mee Sup dan bangunan Blok E di FSSK }\end{array}$ \\
\hline SL 7 & $\begin{array}{l}2^{\circ} 92^{\prime} 79.42 \mathrm{U} \\
101^{\circ} 77^{\prime} 98.75 \mathrm{~T}\end{array}$ & $\begin{array}{l}\text { Kawasan aliran air keluar dari Bangunan F dan } \\
\text { tempat meletak kenderaan ATMA (Alat } \\
\text { pemonitoran kualiti air) }\end{array}$ \\
\hline SL 8 & $\begin{array}{l}2^{\circ} 92^{\prime} 790.47 \mathrm{U} \\
101^{\circ} 77^{\prime} 83.78 \mathrm{~T}\end{array}$ & $\begin{array}{l}\text { Inlet yang menerima aliran air dari longkang FPI, } \\
\text { Canselori dan ATMA }\end{array}$ \\
\hline SL 9 & $\begin{array}{l}2^{\circ} 55^{\prime} 43.70 \mathrm{U} \\
101^{\circ} 46^{\prime} 42.30 \mathrm{~T}\end{array}$ & Inlet daripada Kolej Burhanudin Helmi \\
\hline SL10 & $\begin{array}{l}2^{\circ} 92^{\prime} 98.39 \mathrm{U} \\
101^{\circ} 77^{\prime} 72.01 \mathrm{~T}\end{array}$ & $\begin{array}{l}\text { Kawasan yang menerima aliran air dari longkang } \\
\text { Masjid UKM dan DECTAR }\end{array}$ \\
\hline
\end{tabular}

*SL: Stesen persampelan

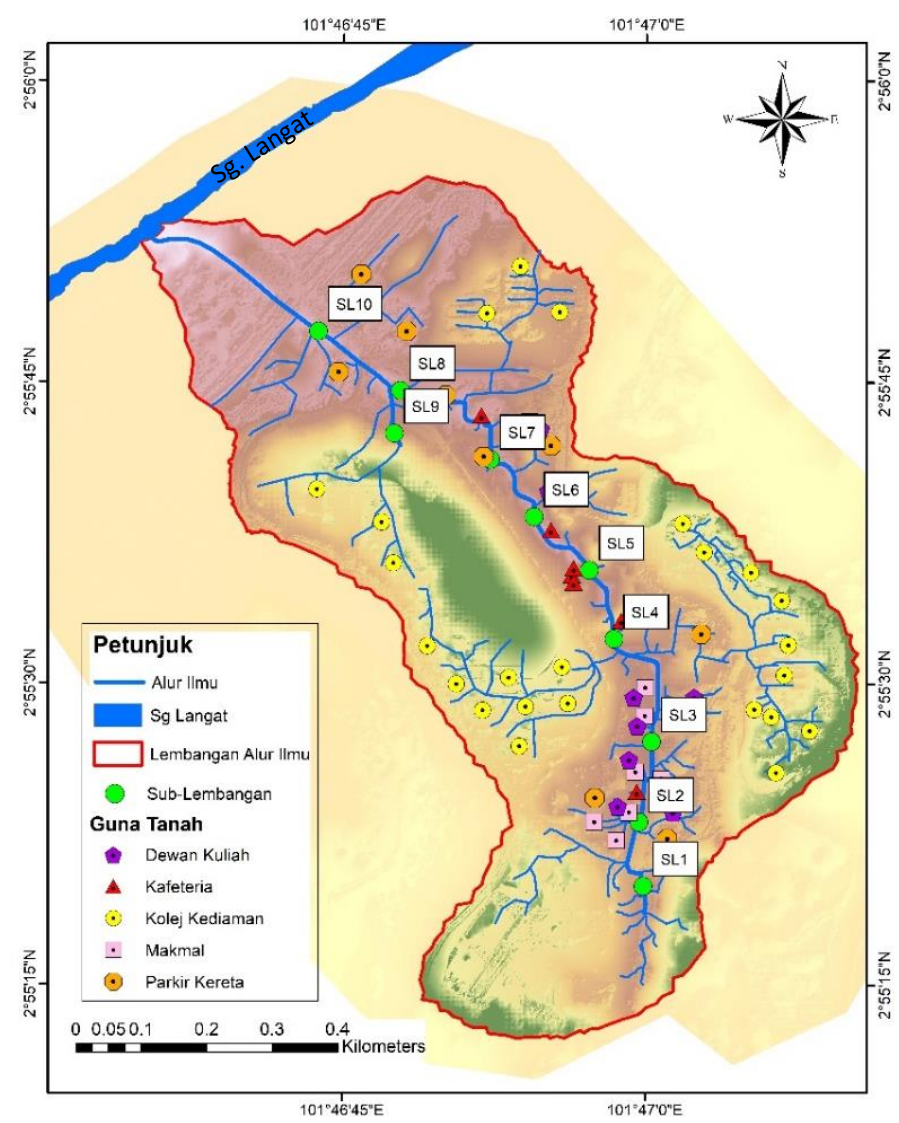

Rajah 2. Kedudukan stesen persampelan dan gunatanah di Alur Ilmu, UKM 


\section{Metodologi kajian}

Dalam kajian ini, kaedah in-situ dan ex-situ dijalankan dalam mengumpul data-data kualiti air Alur Ilmu yang diperlukan. Pengukuran in-situ adalah kaedah pengukuran beberapa parameter yang dilakukan di lapangan secara langsung dengan menggunakan alat bantuan elektronik iaitu YSI Multiparameter. Antara parameter yang diambil terus di lapangan adalah oksigen terlarut (DO) dan suhu dengan menggunakan alat kualiti air PRO 230. Manakala alat Digital $\mathrm{pH}$ Meter digunakan untuk mengukur nilai $\mathrm{pH}$ air di setiap stesen persampelan.

Untuk membuat ujikaji di makmal, sebanyak 300ml sampel air dimasukkan ke dalam botol kaca yang gelap mengikut prosedur yang ditetapkan. Sebanyak 0.5 liter sampel air dimasukkan ke dalam botol plastik untuk ujikaji permintaan oksigen kimia (COD), jumlah pepejal terampai (TSS), permintaan oksigen biokimia (BOD) dan ammonia nitrogen $\left(\mathrm{NH}_{3}-\right.$ N). Kajian ex-situ dalam makmal memerlukan beberapa bahan kimia dan reagent seperti Salicylate dan Cynanurate untuk ujikaji $\mathrm{NH}_{3}-\mathrm{N}$. Selain itu, alatan elektronik seperti alat pencerapan data kualiti air YSI PRO 230, alat Digital pH Meter, dan HACH DR3900 telah digunakan, serta kaedah ujikaji yang dilakukan adalah berdasarkan prosedur yang telah ditetapkan oleh American Public Health Association (APHA) (2005).

Enam parameter kualiti air yang dianalisis iaitu DO, BOD, COD, TSS, $\mathrm{pH}$ dan $\mathrm{NH}_{3}-\mathrm{N}$ dalam menentukan IKA. Enam parameter ini telah digunakan oleh pihak Jabatan Alam Sekitar (JAS) Malaysia dalam menentukan status kualiti air sesuatu badan air khususnya air sungai. IKA ini digunakan untuk membahagikan kualiti air kepada enam kelas dan status air semasa seperti yang ditunjukkan dalam Jadual 2. Julat nilai subindeks (SI) setiap parameter IKA diberikan dalam Jadual 2. IKA ini ditentukan berdasarkan formula yang telah ditetapkan oleh JAS Malaysia seperti persamaan berikut:

$\mathrm{IKA}=(0.22 * \mathrm{SIDO})+(0.19 * \mathrm{SIBOD})+(0.16 * \mathrm{SICOD})+(0.15 *$ SIAN $)+(0.16 *$ SISS $)+$ $(0.12 * \operatorname{SIpH})$

di mana SIDO ialah sub indeks bagi DO; SIBOD ialah sub indeks bagi BOD; SICOD ialah sub indeks bagi COD; SIAN ialah sub indeks bagi $\mathrm{NH}_{3}-\mathrm{N}$; SISS ialah sub indeks bagi SS; $\mathrm{SIpH}$ ialal. sub indeks bagi $\mathrm{pH}$. Jadual 2 menunjukkan pengkelasan IKA berdasarkan parameter ualiti air yang ditetapkan dan Jadual 3 pula menunjukkan status kualiti air berkenaan. Data IKA Alur Ilmu diringkaskan dalam bentuk graf bar garis dan dipersembahkan dalam bentuk peta dengan menggunakan aplikasi Geographical Information System (GIS).

Jadual 2. Pengkelasan IKA JAS Malaysia

\begin{tabular}{lcccccc}
\multicolumn{1}{c}{ Parameter } & Unit & \multicolumn{5}{c}{ Kelas } \\
& & I & IIA/B & III & IV & V \\
Ammonia Nitrogen $\left(\mathrm{NH}_{3}-\mathrm{N}\right)$ & $\mathrm{mg} / \mathrm{l}$ & $<0.1$ & $0.1-0.3$ & $0.3-0.9$ & $0.9-2.7$ & $>2.7$ \\
$\begin{array}{l}\text { Oksigen Biokimia Terlarut } \\
\text { (BOD) }\end{array}$ & $\mathrm{mg} / \mathrm{l}$ & $<1$ & $1-3$ & $3-6$ & $6-12$ & $>12$ \\
$\begin{array}{l}\text { Oksigen Kimia Terlarut } \\
\text { (COD) }\end{array}$ & $\mathrm{mg} / \mathrm{l}$ & $<10$ & $10-25$ & $25-50$ & $50-100$ & $>100$ \\
$\begin{array}{l}\text { Oksigen Terlarut (DO) } \\
\text { pH }\end{array}$ & $\mathrm{mg} / 1$ & $>7$ & $5-7$ & $3-5$ & $1-3$ & $<1$ \\
Pepejal Terampai (SS) & - & $>7$ & $6-7$ & $5-6$ & $<5$ & $>5$ \\
Indeks Kualiti Air (IKA) & $\mathrm{mg} / 1$ & $<25$ & $25-50$ & $50-150$ & $150-300$ & $>300$ \\
\hline
\end{tabular}

Sumber: Jabatan Alam Sekitar (2011) 
Jadual 3. Status sungai berdasarkan IKA

\begin{tabular}{cc}
\hline Kelas & Status \\
\hline I $(>92.7)$ & Sangat Baik \\
II $(76.5-92.7)$ & Baik \\
III $(51.9-76.5)$ & Sederhana \\
IV $(31-51.9)$ & Tercemar \\
V $(<30)$ & Sangat Tercemar \\
\hline
\end{tabular}

Sumber: Jabatan Alam Sekitar (2011)

\section{Hasil kajian dan perbincangan}

\section{Status semasa kualiti air Alur Almu}

Di Malaysia, penentuan terhadap kualiti air sesuatu badan air khususnya sumber air permukaan seperti air sungai akan menggunakan IKA yang telah ditetapkan oleh JAS Malaysia. Secara keseluruhannya, IKA Alur Ilmu semasa cerapan cuaca kering berada dalam status baik di antara nilai IKA 81 hingga 88.5 kecuali di Stesen 5 dan 6. Nilai IKA tertinggi dicatatkan di Stesen 2 pada 5/7/2019 iaitu 94 dan nilai IKA terendah di Stesen 6 pada 15/7/2019 iaitu 64. Stesen 5 dan Stesen 6 mencatatkan status IKA sederhana iaitu dengan nilai purata iaitu 70 dan 69 (Rajah 3). Stesen 5 dan Stesen 6 adalah terletak di kawasan yang menerima aliran air dari longkang Bangunan Bilik Kuliah FSSK dan Pusanika serta kawasan yang menerima aliran air dari Kafeteria Mee Sup dan bangunan Blok E di FSSK (Foto 1 \& Foto 2).

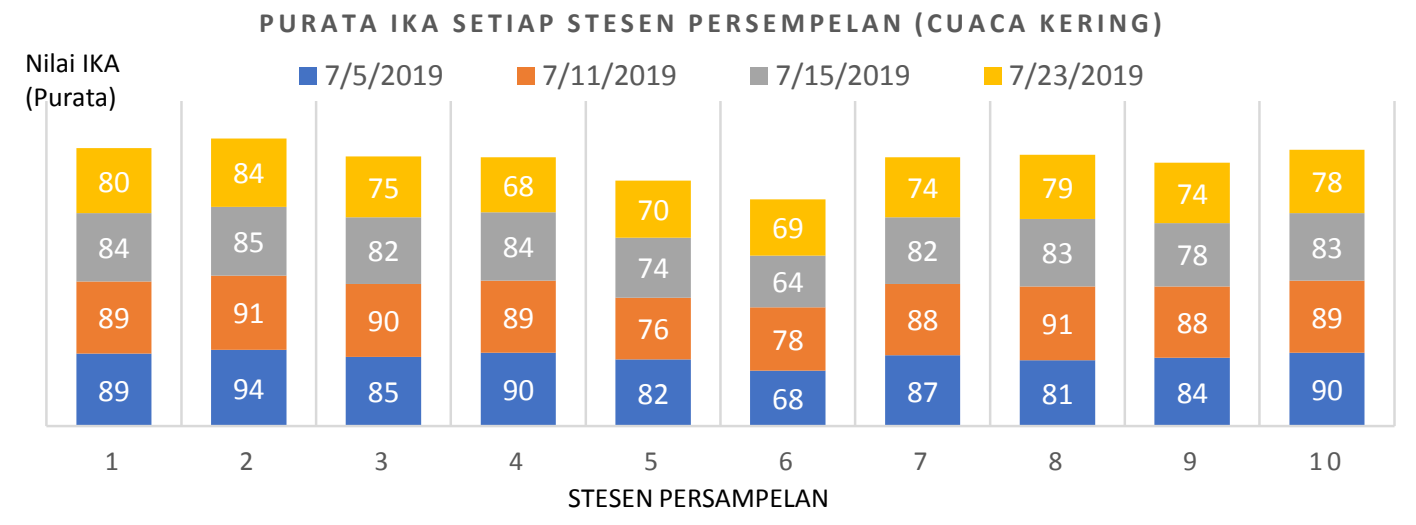

Rajah 3. IKA Alur Ilmu berdasarkan stesen cerapan semasa cuaca kering

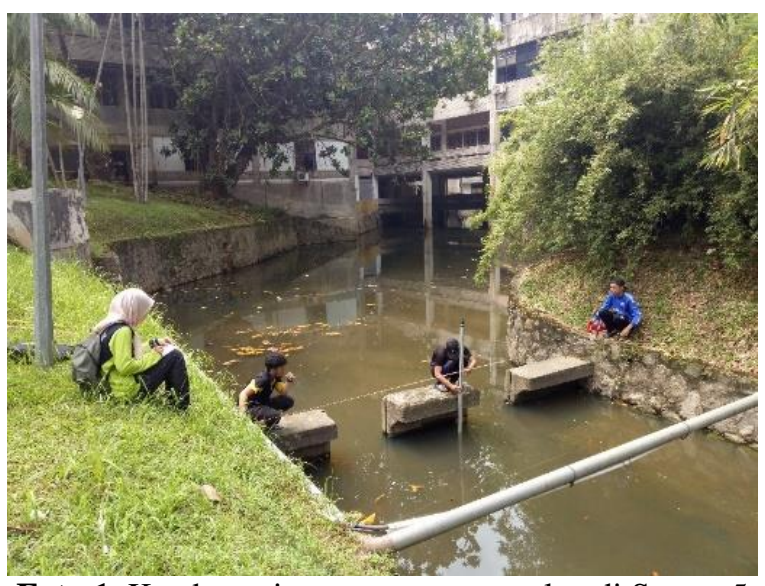

Foto 1. Keadaan air semasa persempelan di Stesen 5

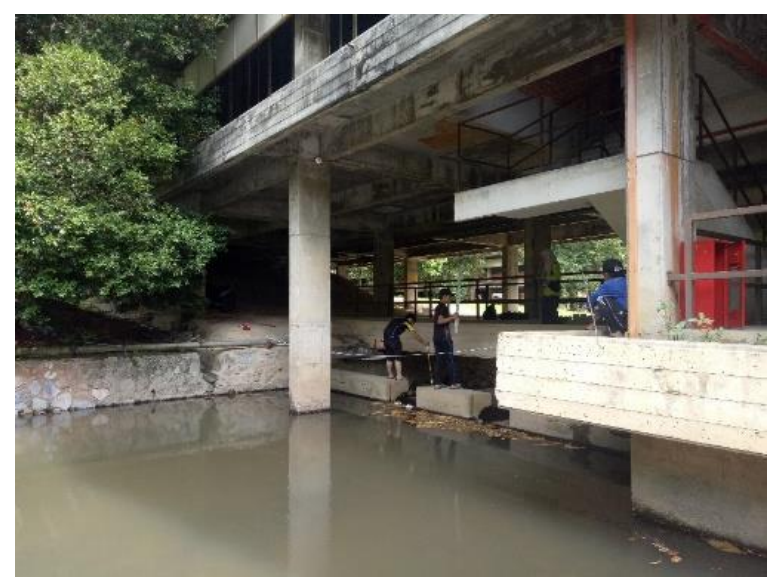

Foto 2. Keadaan air semasa persempelan di Stesen 6 
Sementara itu, IKA Alur Ilmu pada cerapan cuaca basah dan selepas hujan menunjukkan status baik kecuali di Stesen 6. Walau bagaimanapun, nilai IKA yang direkodkan adalah lebih rendah berbanding cerapan semasa cuaca kering kecuali di Stesen 5 . Ini menunjukkan kualiti air berada pada status yang lebih baik semasa cuaca kering berbanding cuaca basah. Keadaan ini bertepatan dengan kajian kualiti air yang telah dilakukan oleh pengkaji-pengkaji sebelum ini yang menunjukkan kualiti air badan air sama ada air sungai atau air bawah tanah berada dalam kualiti yang lebih baik berbanding semasa musim kering berbanding musim basah (Mohd Hafiyyan, 2019) Nilai IKA tertinggi ialah 86 dicatatkan di Stesen 1 (23/8/2019) dan Stesen 7 (7/7/2019). Nilai IKA terendah dicatatkan di Stesen 6 pada 22/7/2019 dengan nilai 50 (Rajah 4). Nilai ini menunjukkan kualiti air di stesen berkenaan berada pada status tercemar iaitu pada Kelas IV.

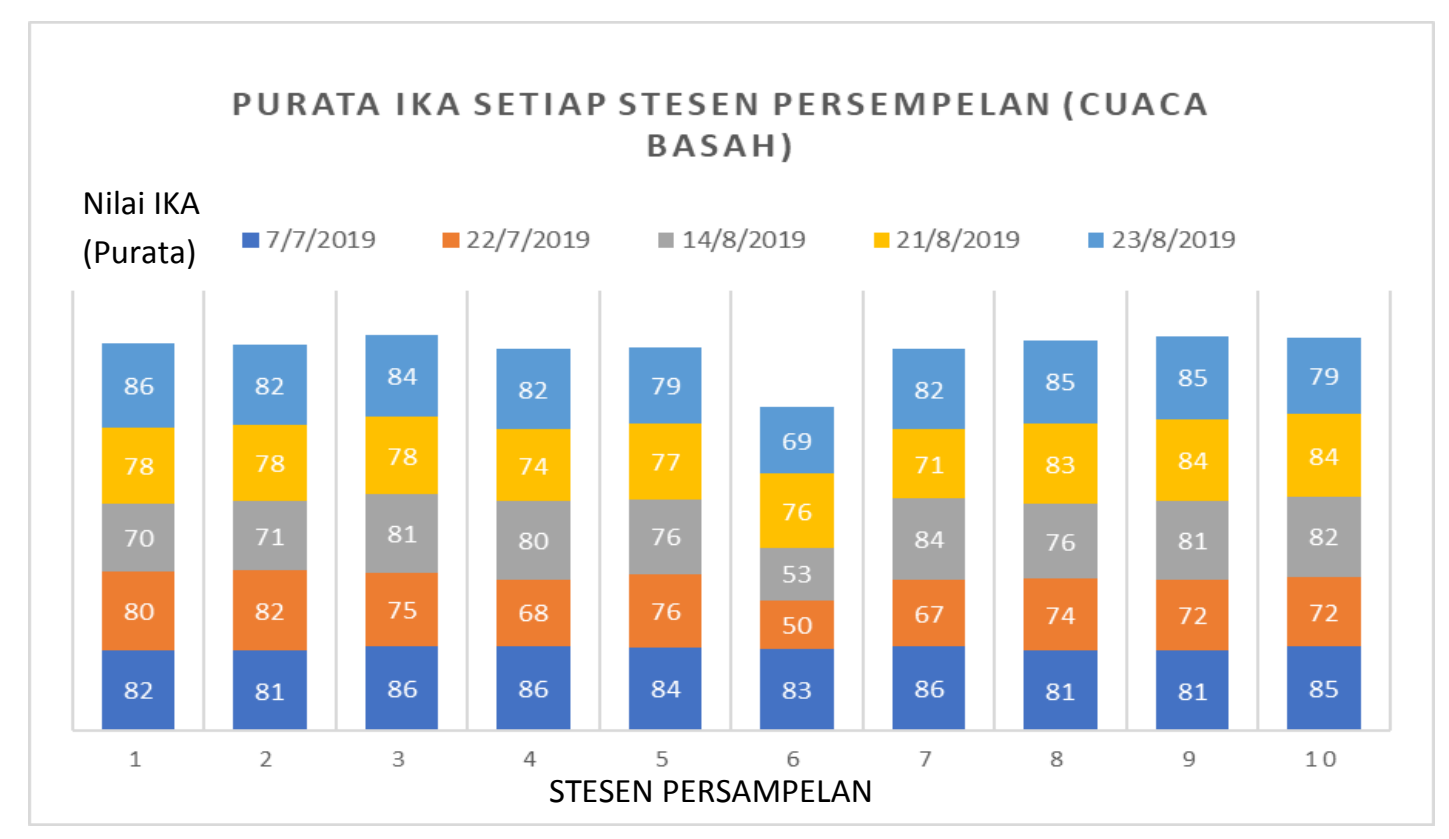

Rajah 4. IKA Alur Ilmu berdasarkan stesen cerapan semasa cuaca basah

Seterusnya purata IKA Alur Ilmu ditunjukkan dalam bentuk peta menggunakan aplikasi GIS seperti yang ditunjukkan dalam Rajah 5, Rajah 6 dan Rajah 7. Pengelasan terhadap IKA bagi Alur Ilmu ini dibezakan warna yang berbeza iaitu warna biru bagi IKA Kelas II yang berada pada status baik (76.5-92.7) dan warna kuning bagi IKA Kelas II yang berada pada status sederhana (51.9-76.5). Berdasarkan rajah-rajah tersebut jelas menunjukkan kawasan tengah Alur Ilmu mengalami status kualiti air yang sederhana tercemar memandangkan kawasan ini berkemungkinan besar menerima aliran air yang dibuang terus daripada dari kiosk penjaja makanan di FSSK dan Pusanika. 
GEOGRAFIA Online ${ }^{\mathrm{TM}}$ Malaysian Journal of Society and Space 16 issue 1 (112-125)

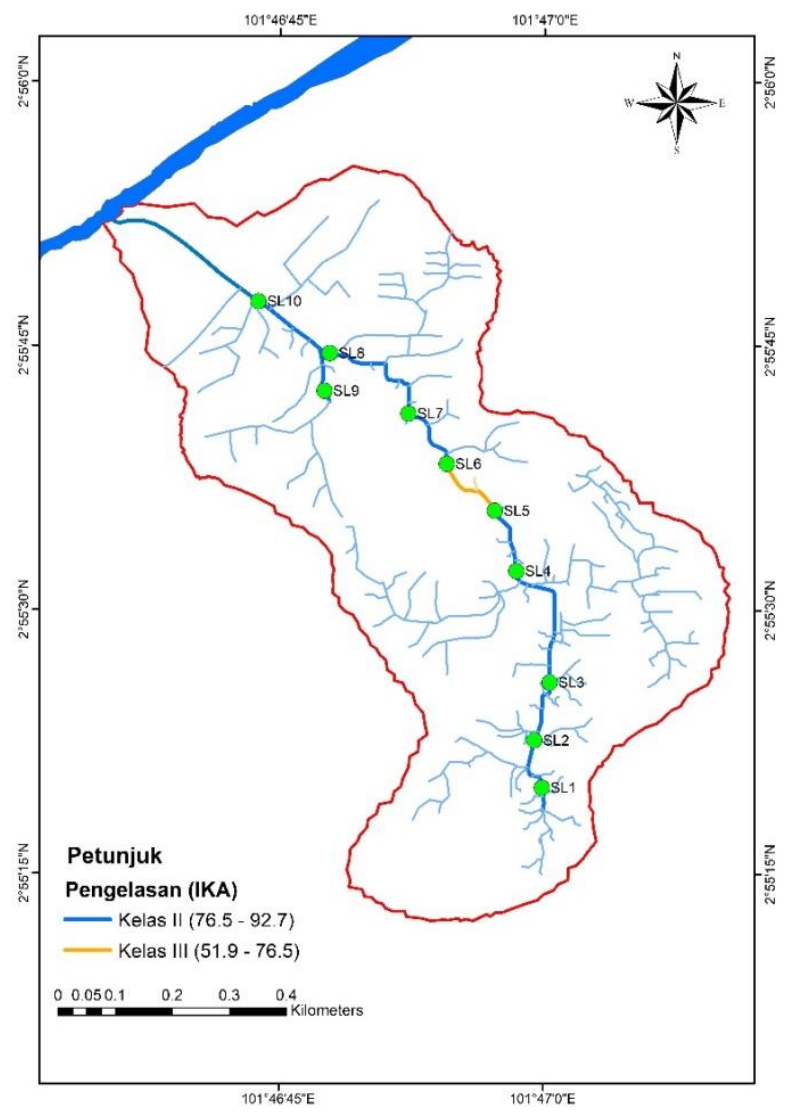

Rajah 5. Pemetaan purata pengelasan IKA di setiap stesen persampelan semasa cuaca kering

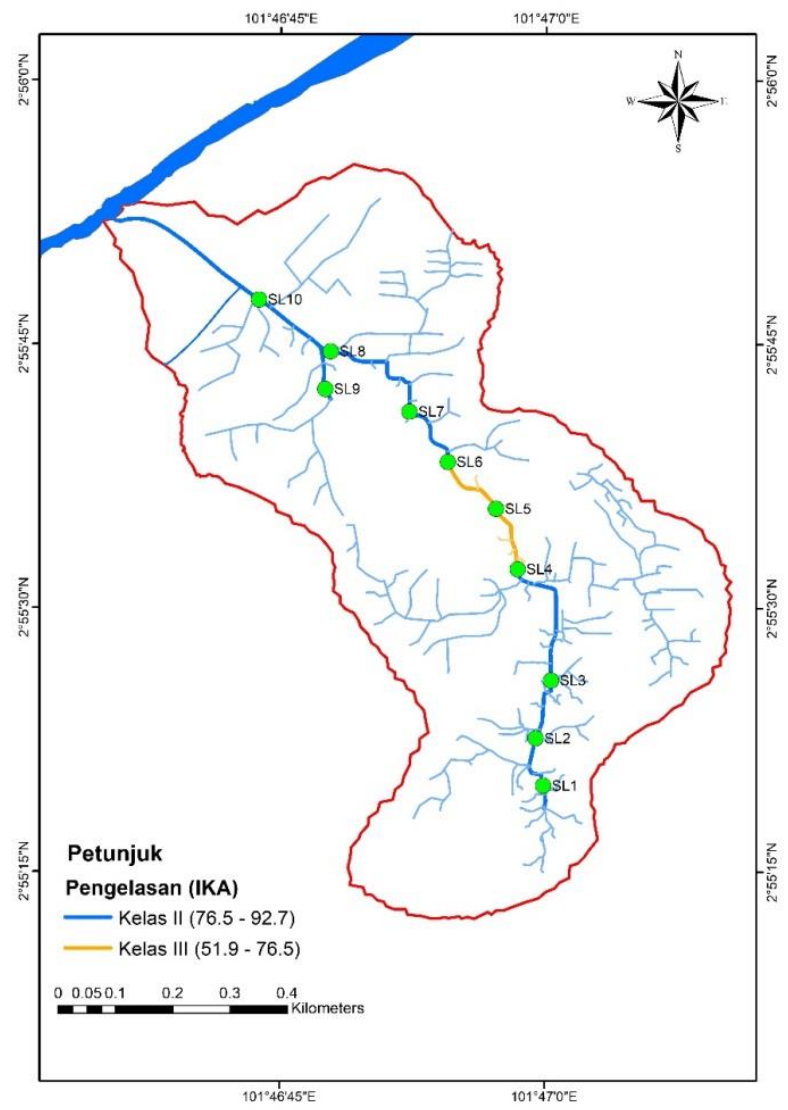

Rajah 6. Pemetaan purata pengelasan IKA di setiap stesen persampelan semasa cuaca basah 


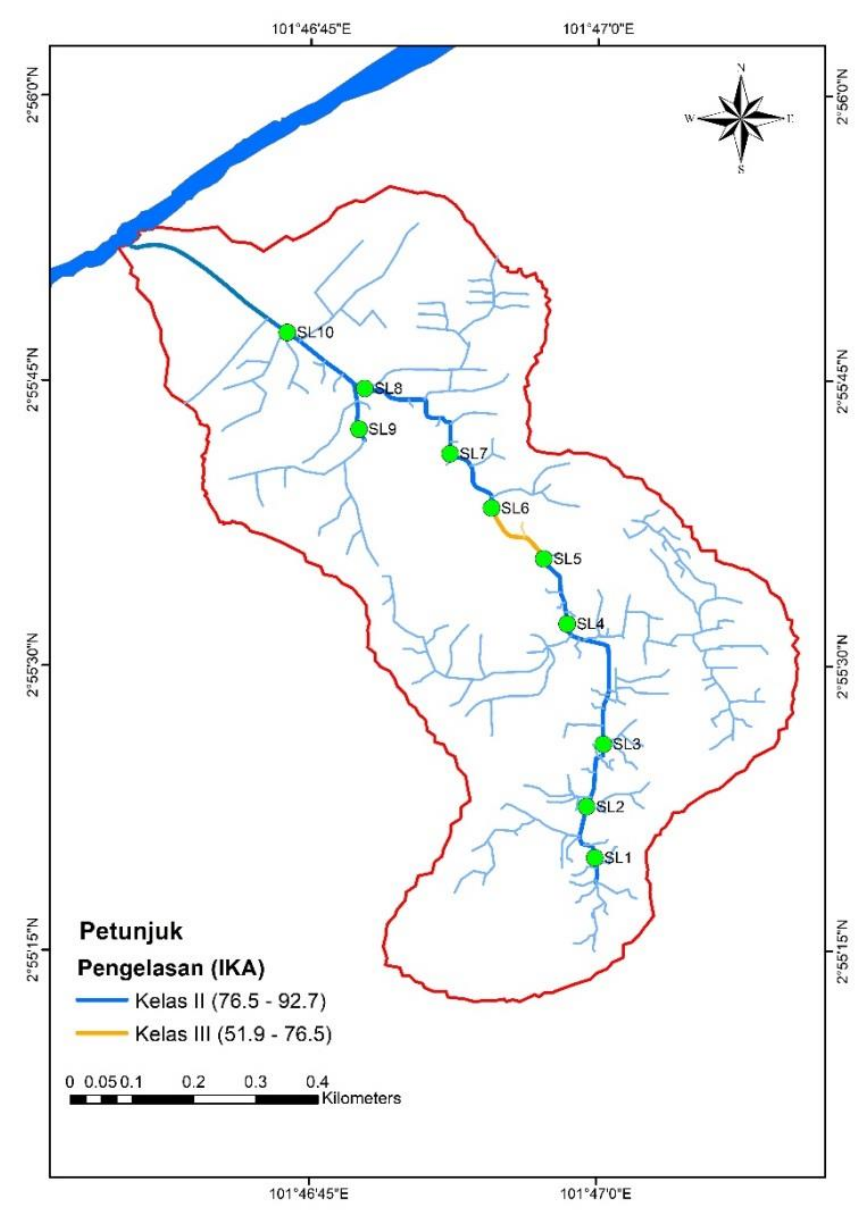

Rajah 7. Pemetaan purata pengelasan IKA di setiap stesen persampelan semasa cuaca basah dan cuaca kering sepanjang Jun 2019 sehingga Ogos 2019

Secara keseluruhannya lembangan sungai Alur Ilmu ini berada pada status kualiti air baik. Nilai IKA Alur Ilmu ini pada cuaca kering adalah 81.7 dan semasa cuaca basah ialah 78 iaitu berada pada Kelas IIB. Kelas IIB jika dirujuk dalam konteks penggunaan air tersebut ialah ia boleh dirawat secara konvensional terlebih dahulu sebelum digunakan untuk bekalan air domestik, sesuai untuk spesies hidupan akuatik yang sensitif dan boleh digunakan untuk tujuan rekreasi berasaskan air. Status kualiti air yang baik ini perlu dikekalkan memandangkan kampus induk UKM mengamalkan konsep kampus lestari. Pemantauan secara berterusan perlu dilakukan terutamanya berkaitan dengan pembangunan infrastruktur yang akan dilakukan di sekitar kampus yang akhirnya boleh menjejaskan kualiti air Alur Ilmu.

\section{Status kualiti air Alur Ilmu jangkamasa panjang 1999-2019}

Kajian terhadap status kualiti air di sub lembangan Sungai Langat iaitu Alur Ilmu UKM (Rajah 8) sentiasa dilakukan dan menarik minat ramai penyelidik (Chong, 1999; Din et al., 2012; Afina et al., 2015; Mohd Hafiyyan et al., 2017). Kajian kualiti air di Alur Ilmu UKM dimulakan oleh Chong (1999) dengan menggunakan IKA untuk menilai status dan tahap kualiti air di sepanjang lembangan Alur Ilmu. Chong (1999) mendapati tahap IKA pada waktu itu berada dalam Kelas III iaitu sederhana tercemar. 


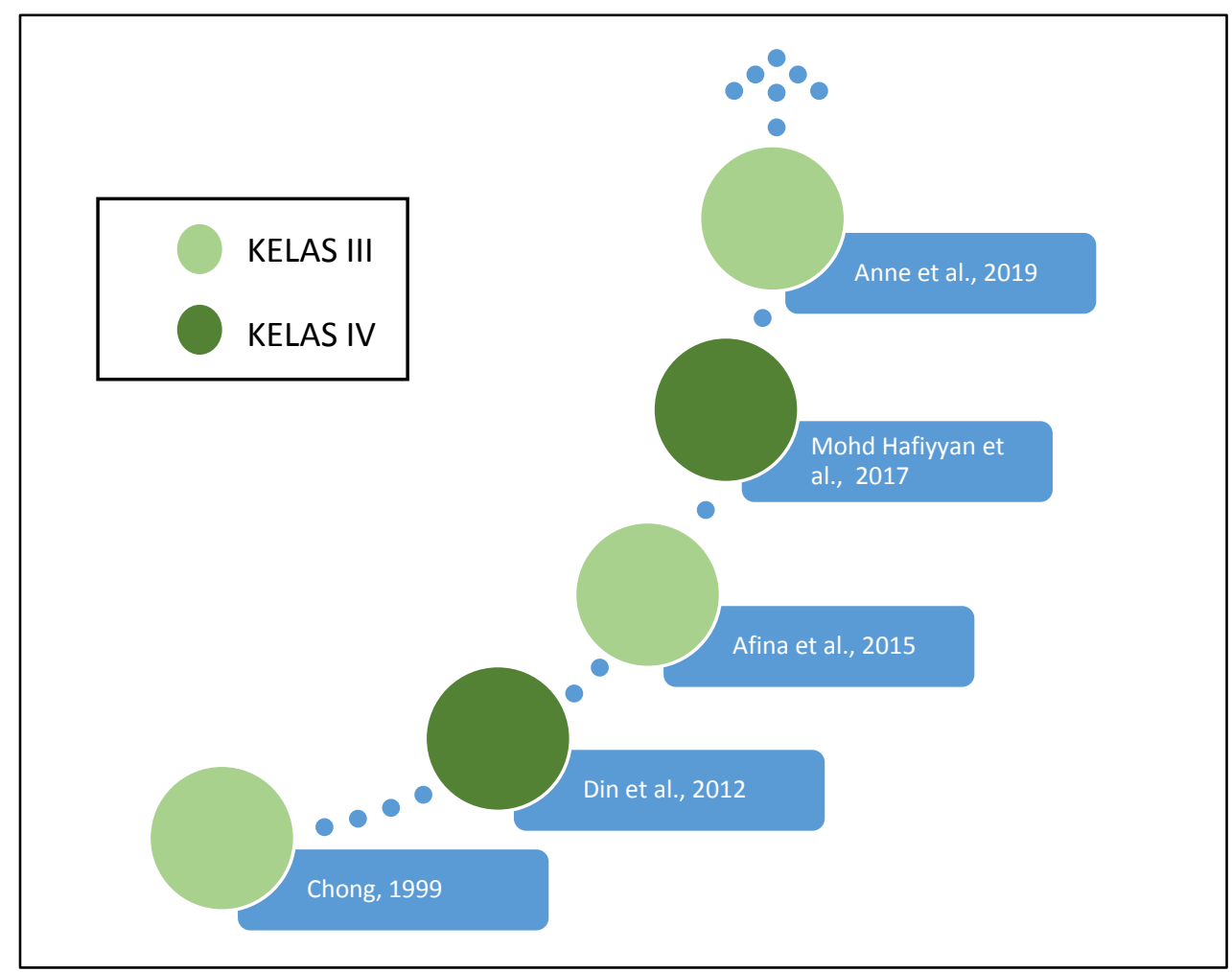

Rajah 8. Kajian kualiti air Alur Ilmu oleh pelbagai pengkaji

Kajian ini seterusnya dibandingkan dengan dapatan kajian yang yang dilakukan oleh Din et al. (2012). Dapatan kajian telah mencatatkan nilai IKA yang lebih rendah iaitu pada Kelas IV iaitu berada pada status tercemar. Penurunan kelas dan status kualiti air ini berpunca daripada aktiviti antropogenik di samping kejadian hujan berpanjangan yang secara tidak langsung telah melebihi aras maksimum kemampuan perangkap sedimen yang telah dibina di bahagian hulu di Tasik Ghazali. Selain itu, aktiviti pembinaan bangunan-bangunan di sekitar kawasan Alur Ilmu pada ketika itu, telah mempengaruhi kualiti air semasa kajian dilakukan dan menyebabkan nilai IKA pada waktu itu menjadi lebih teruk dan rendah iaitu pada Kelas IV.

Seterusnya penilaian status kualiti air turut menarik perhatian pengkaji iaitu Afina et al. (2015). Kajian mendapati tahap IKA pada waktu itu adalah dalam keadaan yang lebih baik iaitu pada Kelas III atau sederhana tercemar. Walau bagaimanapun, kajian pada waktu itu telah mendapati punca kepada masalah penurunan kualiti air adalah disumbangkan oleh aktiviti di kawasan Eco-Teres Niaga, FEP yang terdedah dengan pembuangan sisa-sisa cecair atau pepejal daripada kafe berkenaan.

Dalam pada itu, satu inisiatif dan kajian penambahbaikan telah dijalankan oleh Mohd Hafiyyan et al. (2017) dalam usaha membaiki dan mengurangkan masalah kualiti air di Alur Ilmu khususnya di kawasan hulu. Antara usaha yang dilakukannya adalah seperti pembinaan paya buatan di bahagian hulu, pembuatan dinding turapan telap di beberapa kawasan yang berpotensi bertujuan menahan sedimen atau lumpur. Selain itu, penciptaan beberapa buah paya rawatan terapung turut dilakukan untuk menapis dan memproses nutrien-nutrien atau pepejal terampai di dalam badan air. Selain itu, ia juga berfungsi sebagai pengawalan masalah $\mathrm{BOD}, \mathrm{NH}_{3}-\mathrm{N}$ dan TSS. Hasil daripada ketiga-tiga rawatan yang telah dijalankan ini, telah dapat membantu mengurangkan masalah kemerosotan kualiti air di Alur Ilmu iaitu daripada berada pada Kelas III pada tahun 2016 bertambah baik kepada Kelas II iaitu status baik. 
Seterusnya bagi tujuan kesinambungan kajian kualiti air di Alur Ilmu ini, kajian yang terbaru telah dilakukan pada tahun 2019 dan mendapati nilai IKA Alur Ilmu UKM berada dalam Kelas III. Melalui pemerhatian di sepanjang kawasan kajian yang telah dilakukan juga mendapati bahawa aktiviti membaikpulih atau langkah mitigasi yang telah dilakukan oleh Mohd Hafiyyan et al. (2017) tidak lagi diteruskan. Keadaan ini mungkin disebabkan oleh faktor kewangan atau kekurangan dana yang diperuntukan untuk meneruskan rawatan tersebut. Dalam pada itu, aktiviti antropogenik yang dilakukan oleh manusia seperti pembuangan sisa-sisa makanan dan sampah juga telah mempengaruhi kualiti air dan keadaan Alur Ilmu UKM.

Justeru itu, disarankan bahawa kajian rawatan yang telah dilakukan sebelum ini, perlu diteruskan dan diberi keutamaan demi memastikan tahap IKA Alur Ilmu berada dalam keadaan yang bersih dan baik. Secara tidak langsung, sub lembangan sungai Langat ini tidak menjadi penyumbang utama kepada kemerosotan kualiti air Sungai Langat menjadi lebih teruk. Kerjasama daripada semua pihak terutamanya Jabatan Prasarana UKM yang bertanggungjawab bagi memastikan kelestarian UKM terjaga dengan cara memberi perhatian yang sepenuhnya kepada Alur Ilmu ini.

\section{Kesimpulan}

Lembangan Alur Ilmu sangat penting dalam konteks pengekalan kampus lestari di UKM. Alur Ilmu yang mengalir dari Hutan Simpan Bangi dan keluar di Sungai Langat ini masih mengekalkan status kualiti air yang baik dan bersih iaitu berada pada nilai IKA 81.7 pada cerapan cuaca kering dan nilai 78 semasa cerapan cuaca basah/hujan. Nilai IKA pada cerapan semasa cuaca basah adalah lebih rendah berbanding cuaca kering dan faktor ini boleh dikaitkan dengan faktor hujan yang telah mempengaruhi kualiti air Alur Ilmu ini. Kualiti air Alur Ilmu ini juga berada pada Kelas II.

Beberapa lokasi persampelan telah dikenalpasti yang menyebabkan kualiti air Alur Ilmu berada pada status sederhana tercemar. Hasil kajian ini boleh digunakan sebagai alat yang berkesan untuk menyelesaikan masalah alam sekitar khususnya dalam usaha kawalan pencemaran, selain dapat memberi pengetahuan dalam memaksimumkan keupayaan sistem rawatan air untuk perlindungan strategik dan dapat menentukan tahap kualiti air di kawasan tertentu dalam masa yang singkat dan melibatkan kos rendah. Pemantauan secara berterusan sangat diperlukan agar kualiti air Alur Ilmu ini berada pada status baik dan tidak menjadi pula penyumbang kepada masalah pencemaran air Sungai Langat.

\section{Penghargaan}

Penulis ingin merakamkan penghargaan di atas sokongan kewangan yang disediakan oleh Universiti Kebangsaan Malaysia melalui geran KRA 2017-035 (Kajian Siri Masa Sebenar Luahan dan Kualiti Air Alur Ilmu, Sub Lembangan Sungai Langat, Selangor).

\section{Rujukan}

Afina, N.A.M., Othman, A.K., \& Ahmad, D.M. (2015). The water quality study and sources of pollution in Alur Ilmu, UKM. The Malaysian Journal of Analytical Sciences, 19(5), $1137-1146$. 
APHA. (2005). Standard methods for the examination of water and wastewater (21st Edition). Washington, D.C.: American Public Health Association.

Azahan Awang, Jamaluddin Md. Jahi, \& Mohamad Suhaily Yusri Che Ngah. (2001). Status dan pengurusan kualiti air Sungai Linggi. Dlm. Jamaluddin, M.J., \& Mohd Jailani, M.N. (pnyt), Proceeding National Seminar on Environmental Management: Current Development \& Future Planning. Universiti Kebangsaan Malaysia, Bangi. 14-15 Ogos, 2011.

Bedient, P., \& Huber, W. (1988). Hydrology and floodplain analysis. Massachusetts, AddisonWesley Pub.

Chong, W.L. (1999). Kajian efluen kolam pengoksidaan kumbahan dan sistem saliran sekitar kampus UKM. Tesis Ijazah Sarjana Muda Sains dengan Kepujian, FST, UKM (tidak diterbitkan).

Din, H.M., Toriman, M.E., Mokhtar, M., Elfithri, R., Aziz, N.A.A, Abdullah, N.M., \& Kamarudin, M.K.A. (2012). Kepekatan beban bahan pencemar di Alur Ilmu kampus UKM Bangi: Kaedah min kepekatan peristiwa. The Malaysian Journal of Analytical Sciences, 16(3), 353-365.

Global Water Partnership. (2009). Global water security: Submission by the Global Water Partnership to ICE/RAE/CIWEM Report to Professor John Beddington, Chief Scientific Adviser to HM Government.

Hassan Mohammed Ali Alssgeer, Muhammad Barzani Gasim, Marlia M. Hanafiah, Elhadi Ramadan Ali Abdulhadi, \& Azman Azid. (2018). GIS-based analysis of water quality deterioration in the Nerus River, Kuala Terengganu, Malaysia. Desalination and Water Treatment, 112, 334-343.

Jabatan Alam Sekitar Malaysia. (2011). Laporan kualiti alam sekeliling 2010. Putrajaya, Kementerian Sumber Asli \& Alam Sekitar.

Katiman Rostam, \& Asmah Ahmad. (2006). Penilaian dan pengurusan sumber alam. Bangi, Penerbit Universiti Kebangsaan Malaysia.

Lazaro, T.R. (1990). Urban hydrology: A multidisciplinary perspective (Revised edition). Lancaster, Technomic Publishing Com Inc.

Mazlin, M., Chee, F.H., Chong, W.L., Ooi, Y.Y., \& Tan, B.H. (2005). Kajian kualiti udara 'Alur Ilmu' di kampus UKM Bangi: Ke arah pendekatan pengurusan sumber udara bersepadu. The Malaysian Journal of Analytical Sciences, 12(3), 388 -395.

Miller, T. (2005). Living in the environment. Australia, Thomson Learning.

Mohd Hafiyyan Mahmud. (2019). Pembentukan kerangka pengurusan bersepadu sungai bandar Alur Ilmu ke arah pemuliharaan dan pemeliharaan sumber air. Tesis $\mathrm{PhD}$ Universiti Kebangsaan Malaysia (tidak diterbitkan).

Mohd Hafiyyan, M., Lee, K.E., Mazlin, M., Marfiah, A.W., Goh, T.L., Norbert, S., Marlia, M.H., \& Azhar, A.H. (2017). Spatial distribution of water quality index in stormwater channel: A case study of Alur Ilmu, UKM Bangi Campus. Asia Pacific Environmental and Occupational Health Journal, 3(1), 33-38.

Nasir Nayan. (2006). Persekitaran sistem maklumat geografi (GIS). Tanjong Malim, Penerbit Universiti Pendidikan Sultan Idris Shah.

Norhazlina Eazreen Harun. (2006). Kajian penentuan kawasan bukit berisiko menggunakan sistem maklumat geografi (GIS). Tesis Sarjana Muda Universiti Teknologi Malaysia (tidak diterbitkan).

Rasyidah Abd Aziz. (2014). Water quality study of Melaka River using WQI, Remote Sensing and GIS. Tesis Sarjana Sains, Universiti Teknologi MARA (tidak diterbitkan).

Ruslan Ranis \& Noresah Mohd Shariff. (1998). Sistem maklumat geografi. Kuala Lumpur, Dewan Bahasa dan Pustaka. 
Schueler, T.R. (1994). The importance of imperviousness. Watershed Protection Techniques, 1(3), 100-111.

Shaharuddin Ahmad, \& Noorazuan Mohd Hashim. (2006). Menganalisis pola dan arah aliran hujan di Negeri Sembilan menggunakan kaedah GIS poligon Thiessen dan kontur Isoyet. Geografia: Malaysian Journal of Society and Space, 2(1), 105-113.

Tuan Pah Rokiah Syed Hussain, \& Hamidi Ismail. (2016). Perubahan gunatanah dan kejadian banjir di lembangan saliran Kelantan. Geografia: Malaysian Journal of Society and Space, 12(1), 118-128.

Tuan Pah Rokiah Syed Hussain, Hamidi Ismail, \& Mat Khalid Md Noh. (2015). Perubahan guna tanah dan taburan hujan luar biasa di daerah-daerah pedalaman negeri Kedah. Geografia: Malaysian Journal of Society and Space, 11(7), 58-69.

Veerabhadram, K. (2009). Mapping of water quality index (WQI) using Geographical Information System (GIS) as decision supporting system tool. Diperoleh daripada https://www.geospatialworld.net/article/mapping-of-water-quality-index-wqi-usinggeographical-information-system-gis-as-decision-supporting-system-tool

World Health Organization. (2006). Guidelines for drinking-water quality. Medical, 1, 68p. 